\title{
Hubungan Usia, Jenis Kelamin dan Hipertensi dengan Kejadian Diabetes Mellitus Tipe 2 di Puskesmas Tugu Kecamatan Cimanggis Kota Depok
}

\author{
The Relationship Between Age, Sex And Hypertension With The Incidence Of \\ Type 2 Diabetes Mellitus In Tugu Public Health Center, Cimanggis District, \\ Depok City in 2019 \\ Susilawati $^{(1)}$, Rista Rahmawati ${ }^{(1)}$
}

${ }^{(1)}$ Prodi S1 Kesehatan Masyarakat STIKes Raflesia Depok

Korespondensi Penulis: Susilawati, Prodi S1 Kesehatan Masyarakat

STIKes Raflesia Depok

Email: susi280570@gmail.com

\begin{abstract}
ABSTRAK
Diabetes mellitus adalah salah satu penyakit tidak menular yang hingga saat ini menunjukkan peningkatan. Faktor-faktor yang dapat menyebabkan terjadinya diabetes mellitus tipe 2 diantaranya adalah usia, jenis kelamin dan hipertensi. Penelitian ini bertujuan untuk mengidentifikasi hubungan usia, jenis kelamin dan hipertensi dengan kejadian diabetes mellitus tipe 2 di Puskesmas Tugu Kecamatan Cimanggis Kota Depok tahun 2019. Metode penelitian ini adalah survei analitik dengan rancangan case control. Sampel penelitian ini terdiri dari 132 sampel kelompok kasus dan 132 sampel kelompok kontrol. Pengumpulan data yang digunakan dalam penelitian ini yaitu data sekunder. Analisis untuk uji hipotesis menggunakan uji statistik chi-square dengan $\alpha=0,05$ dan CI $=95 \%$. Hasil penelitian menunjukkan bahwa ada hubungan antara usia dengan kejadian diabetes mellitus tipe 2 dengan nilai $\mathrm{p}$ value $=0,000<\alpha(0,05)$ dan nilai $\mathrm{OR}=18,143(95 \% \mathrm{CI} 6,959-47,302)$. Tidak ada hubungan antara jenis kelamin dengan kejadian diabetes mellitus tipe 2 dengan nilai $\mathrm{p}$ value $=0,519>\alpha(0,05)$ dan nilai $\mathrm{OR}=1,222$ (95\% CI 0,736-2,029). Tidak ada hubungan antara hipertensi dengan kejadian diabetes mellitus tipe 2 dengan nilai $\mathrm{p}$ value $=0,879>\alpha(0,05)$ dan nilai $\mathrm{OR}=1,098(95 \%$ CI $0,603-1,997)$. Determinan yang berhubungan dengan kejadian diabetes mellitus tipe 2 adalah usia. Sedangkan determinan yang tidak berhubungan dengan kejadian diabetes mellitus tipe 2 adalah jenis kelamin dan hipertensi.
\end{abstract}

Kata Kunci: Usia, Jenis Kelamin, Hipertensi, Diabetes Mellitus tipe 2

\section{ABSTRACT}

Diabetes mellitus is one of the non-communicable diseases that has shown an increase to date. The factors that can cause type 2 diabetes mellitus include age, gender and hypertension. This study aims to identify the relationship between age, sex and hypertension with the incidence of type 2 diabetes mellitus in Tugu Public Health Center, Cimanggis District, Depok City in 2019.

This research method is an analytic survey with a case control design. The sample of this study consisted of 132 samples of the case group and 132 samples of the control group. Data collection used in this study is secondary data. Analysis for hypothesis testing using the chi-square statistical test with $\alpha=0,05$ and $C I=95 \%$. The results showed that There was a relationship between age and the incidence of type 2 diabetes mellitus with $p$ value = $0,000<\alpha(0,05)$ and $O R=18,143$ (95\% CI 6,959-47,302). There was no relationship between gender and the incidence of type 2 diabetes mellitus with $p$ value $=0,519>\alpha(0,05)$ and $O R=1,222(95 \%$ CI 0,736-2,029). There is no relationship between hypertension and the incidence of type 2 diabetes mellitus with $p$ value $=0,879$ $>\alpha(0,05)$ and $O R=1,098(95 \%$ CI 0,603-1,997).

The determinant associated with the incidence of type 2 diabetes mellitus is age. Meanwhile, the determinant that were not related to the incidence of type 2 diabetes mellitus were gender and hypertension.

Keywords: Age, Gender, Hypertension, Diabetes Mellitus Type 2 


\section{PENDAHULUAN}

Diabetes mellitus merupakan salah satu masalah kesehatan yang menjadi prioritas dari empat penyakit tidak menular (Kemenkes RI, 2019). WHO pada tahun 2011 menyatakan bahwa dari berbagai tipe diabetes mellitus, diabetes mellitus tipe 2 merupakan tipe yang paling tinggi persentase penderitanya yaitu sebesar 90-95\%. Berdasarkan data International Diabetes Federation (IDF) pada tahun 2013, penderita diabetes mellitus tipe 2 sebesar $80 \%$ berada di negara yang berpenghasilan rendah atau menengah dengan rentang usia 40-59 tahun (Nurayati dan Adriani, 2017).

Di seluruh dunia, jumlah penderita diabetes mellitus telah mengalami peningkatan dari 108 juta orang di tahun 1980 menjadi 422 juta orang pada tahun 2014 atau meningkat sekitar empat kali lipat (Kemenkes RI, 2019). Hal ini didukung oleh data International Diabetes Federation (IDF) tahun 2017 yang menunjukkan jumlah penderita diabetes mellitus sebanyak 424,9 juta orang dan diperkirakan mengalami peningkatan sebanyak 628,6 juta orang di tahun 2045 (Mildawati dkk, 2019). WHO pada tahun 2016 mengungkapkan bahwa penyakit diabetes mellitus telah menyebabkan 1,5 juta kematian pada tahun 2012. Gula darah yang lebih tinggi dari batas maksimum mengakibatkan 2,2 juta kematian dengan risiko penyakit kardiovaskular dan lainnya. Sekitar 43\% dari 3,7 juta kematian ini terjadi sebelum usia 70 tahun (Kemenkes RI, 2019).

\section{International Diabetes Federation}

(IDF) pada tahun 2013 menyatakan bahwa Indonesia merupakan salah satu negara berkembang dengan angka prevalensi diabetes mellitus tipe 2 ke tujuh terbanyak di dunia dengan angka 8,5 juta penderita setelah Cina 98,4 juta (Boku, 2019). Indonesia telah mengalami peningkatan jumlah penderita diabetes mellitus yaitu dari 7,6 juta orang pada tahun 2013 menjadi 9,1 juta orang di tahun 2015 dan menduduki peringkat ke lima penyakit terbanyak di dunia serta menduduki urutan ke empat penyakit terbanyak di Indonesia (PERKENI, 2015).

International Diabetes Federation (IDF) pada tahun 2014 menyebutkan bahwa lebih dari 10 juta pasien diabetes mellitus menderita kelumpuhan dan komplikasi mengkhawatirkan serta dapat mengancam jiwa seperti serangan jantung, stroke, gagal ginjal, kebutaan, hingga amputansi. Menurut Price dan Wilson tahun 2006 selain berdampak pada tubuh penderita berupa komplikasi, diabetes mellitus juga berdampak buruk dari sisi ekonomi. Diabetes mellitus meningkatkan beban ekonomi berupa biaya medis yang tinggi. Selain itu, bertambahnya populasi lansia yang mengidap penyakit diabetes mellitus membuat beban ekonomi terus meningkat (Widyasari, 2017).

Salah satu faktor yang berhubungan dengan kejadian diabetes mellitus tipe 2 adalah usia. Berdasarkan penelitian (Masruroh, 2018) tentang hubungan umur dan status gizi dengan kadar gula darah penderita diabetes melitus tipe II di Poli Penyakit Dalam RSUD dr. Iskak Tulungagung tahun 2017, menunjukkan bahwa ada hubungan antara umur dengan kadar gula darah pada penderita diabetes melitus tipe II dengan nilai $\mathrm{p}$ value $=0,000$, serta terdapat hubungan antara status gizi dengan kadar gula darah pada penderita diabetes melitus tipe II dengan nilai $\mathrm{p}$ value $=0,000$.

Jenis kelamin termasuk salah satu faktor yang berhubungan dengan terjadinya diabetes mellitus tipe 2. Perempuan cenderung lebih berisiko terkena diabetes mellitus tipe 2 . Hal ini dikarenakan perempuan memiliki kolesterol yang lebih tinggi dibandingkan lakilaki dan juga terdapat perbedaan dalam melakukan semua aktivitas dan gaya hidup sehari-hari yang sangat mempengaruhi kejadian diabetes mellitus tipe 2 . Jumlah lemak pada laki-laki $15-20 \%$ dari berat badan sedangkan perempuan $20-25 \%$ dari berat badan. Jadi peningkatan kadar lemak pada perempuan lebih tinggi dibandingkan laki-laki, sehingga faktor terjadinya diabetes mellitus pada perempuan 3-7 kali lebih tinggi dibandingkan pada laki-laki yaitu 2-3 kali (Imelda, 2019).

Hipertensi juga merupakan salah satu faktor risiko yang berhubungan dengan penyakit diabetes mellitus tipe 2. Tekanan darah yang tinggi menyebabkan distribusi gula pada sel-sel tidak berjalan optimal, sehingga terjadi penumpukan gula dan kolesterol dalam darah. Intinya jika tekanan darah baik, gula darah juga akan terjaga. Insulin bersifat sebagai zat pengendali tekanan darah dan kadar air dalam tubuh, sehingga kadar insulin yang cukup menyebabkan tekanan darah terjaga (Alfiyah, 2011).

Melihat besar masalah penyakit diabetes mellitus di Indonesia dan implikasinya 
ekonominya dan berbagai faktor determinan yang mempengaruhinya dan masalah ini ditemukan pula di Puskesmas Tugu Kecamatan Cimanggis Kota Depok. Ditemukan jumlah pasien yang menderita diabetes mellitus pada bulan Januari-April tahun 2019 ada sebanyak 171 pasien bulan Januari, bulan Februari sebanyak 128 pasien, bulan Maret sebanyak 125 pasien, dan bulan April sebanyak 132 pasien. Nampak bahwa permasalahan penyakit diabetes mellitus masih tinggi di Puskesmas Tugu Depok. Oleh karena itu penulis tertarik melakukan penelitian dengan tujuan mengidentifikasi hubungan usia, jenis kelamin dan hipertensi dengan kejadian diabetes mellitus tipe 2 di Puskesmas Tugu Kecamatan Cimanggis Kota Depok Tahun 2019.

\section{METODE PENELITIAN}

Jenis penelitian ini merupakan desain penelitian survei analitik dengan rancangan case control. Penelitian ini dilakukan di
Puskesmas Tugu Kecamatan Cimanggis Kota Depok pada bulan Juli sampai Agustus tahun 2020. Pengumpulan data yang digunakan dalam penelitian ini yaitu data sekunder yang diambil dari laporan rekam medis pada bulan April tahun 2019. Populasi dalam penelitian ini adalah pasien yang berkunjung ke Puskesmas Tugu yang berusia diatas 15 tahun pada bulan April tahun 2019 sebanyak 2.009 pasien. Besar sampel minimal dihitung dengan menggunakan rumus besar sampel uji hipotesis 2 proporsi (rumus Lemeshow) sehingga didapatkan besar sampel 132 sampel. Perbandingan kasus dan kontrol adalah 1:1 dengan 132 kasus dan 132 kontrol. Teknik pengambilan sampel untuk kelompok kontrol diambil dengan menggunakan metode random sampling. Keterbatasan penelitian ini adalah analisis penelitian dengan analisis bivariate tidak sampai pada multivariate sehingga bisa timbul bias dalam mengestimasi faktor determinan diabetes mellitus.

\section{HASIL}

\section{Analisis Univariat}

1) Distribusi Karakteristik Pasien Berdasarkan Alamat

Tabel 1 Distribusi Frekuensi Pasien Berdasarkan Alamat di Puskesmas Tugu Kecamatan Cimanggis Kota Depok Tahun 2019

\begin{tabular}{|c|c|c|c|}
\hline No & Keterangan & Frekuensi & $\%$ \\
\hline 1. & Alamat & & \\
\hline & RW 01 & 18 & 6,8 \\
\hline & RW 02 & 29 & 11 \\
\hline & RW 03 & 16 & 6 \\
\hline & RW 04 & 13 & 5 \\
\hline & RW 05 & 17 & 6,4 \\
\hline & RW 06 & 15 & 5,7 \\
\hline & RW 07 & 21 & 8 \\
\hline & RW 08 & 35 & 13,2 \\
\hline & RW 09 & 18 & 6,8 \\
\hline & RW 10 & 18 & 6,8 \\
\hline & RW 11 & 27 & 10,2 \\
\hline & RW 12 & 1 & 0,4 \\
\hline & RW 13 & 3 & 1,1 \\
\hline & RW 14 & 1 & 0,4 \\
\hline & RW 15 & 2 & 0,8 \\
\hline & RW 16 & 1 & 0,4 \\
\hline & Diluar kategori/lain-lain & 29 & 11 \\
\hline \multirow[t]{3}{*}{2} & Jenis Kunjungan & & \\
\hline & Baru & 26 & 9,8 \\
\hline & Lama & 238 & 90,2 \\
\hline \multirow[t]{3}{*}{3} & Jenis Bayar & & \\
\hline & Bayar & 61 & 23,1 \\
\hline & BPJS & 203 & 76,9 \\
\hline \multirow[t]{3}{*}{4.} & Jenis Poli & & \\
\hline & Lansia & 112 & 42,4 \\
\hline & Umum & 152 & 57,6 \\
\hline \multirow[t]{3}{*}{5.} & Usia & & \\
\hline & $\geq 45$ Tahun/Berisiko & 204 & 77,3 \\
\hline & <45 Tahun/Tidak Berisiko & 60 & 22,7 \\
\hline
\end{tabular}




\begin{tabular}{|c|c|c|c|}
\hline \multirow[t]{3}{*}{6.} & Jenis Kelamin & & \\
\hline & Perempuan & 172 & 65,2 \\
\hline & Laki-Laki & 92 & 34,8 \\
\hline \multirow[t]{3}{*}{7.} & Kejadian Hipertensi & & \\
\hline & Hipertensi & 54 & 20,5 \\
\hline & Tidak Hipertensi & 210 & 79,5 \\
\hline \multirow[t]{4}{*}{8.} & Kejadian Diabetes Melitus & & \\
\hline & Kasus & 132 & 50 \\
\hline & Kontrol & 132 & 50 \\
\hline & Total & 264 & 100 \\
\hline
\end{tabular}

Berdasarkan tabel 1 di atas menunjukkan bahwa sebagian besar pasien beralamat di RW 08 sebanyak $35(13,2 \%)$ pasien, 90,2\% jenis kunjungan pasien adalah pasien lama, 76,9\% pasien menggunakan jenis bayar BPJS, 57,6\% pasien berada di poli umum, sebagian besar pasien berusia $\geq 45$ tahun sebanyak 204 (77,3\%) pasien, sebagian besar pasien berjenis kelamin perempuan sebanyak 172 (65,2\%) pasien, sebagian besar pasien tidak mengalami hipertensi sebanyak $210 \quad(79,5 \%)$ pasien, kelompok kasus yaitu penderita diabetes mellitus tipe 2 dan kelompok kontrol yaitu bukan penderita diabetes mellitus tipe 2 berjumlah sama masing-masing 132 (50\%) pasien. Perbandingan kasus dan kontrol adalah $1: 1$.

\section{Analisis Bivariat}

Tabel 2 Analisis Hubungan antara Usia, Jenis Kelamin dan Kejadian Hipertensi dengan Kejadian Diabetes Mellitus Tipe 2 di Puskesmas Tugu Kecamatan Cimanggis Kota Depok Tahun 2019

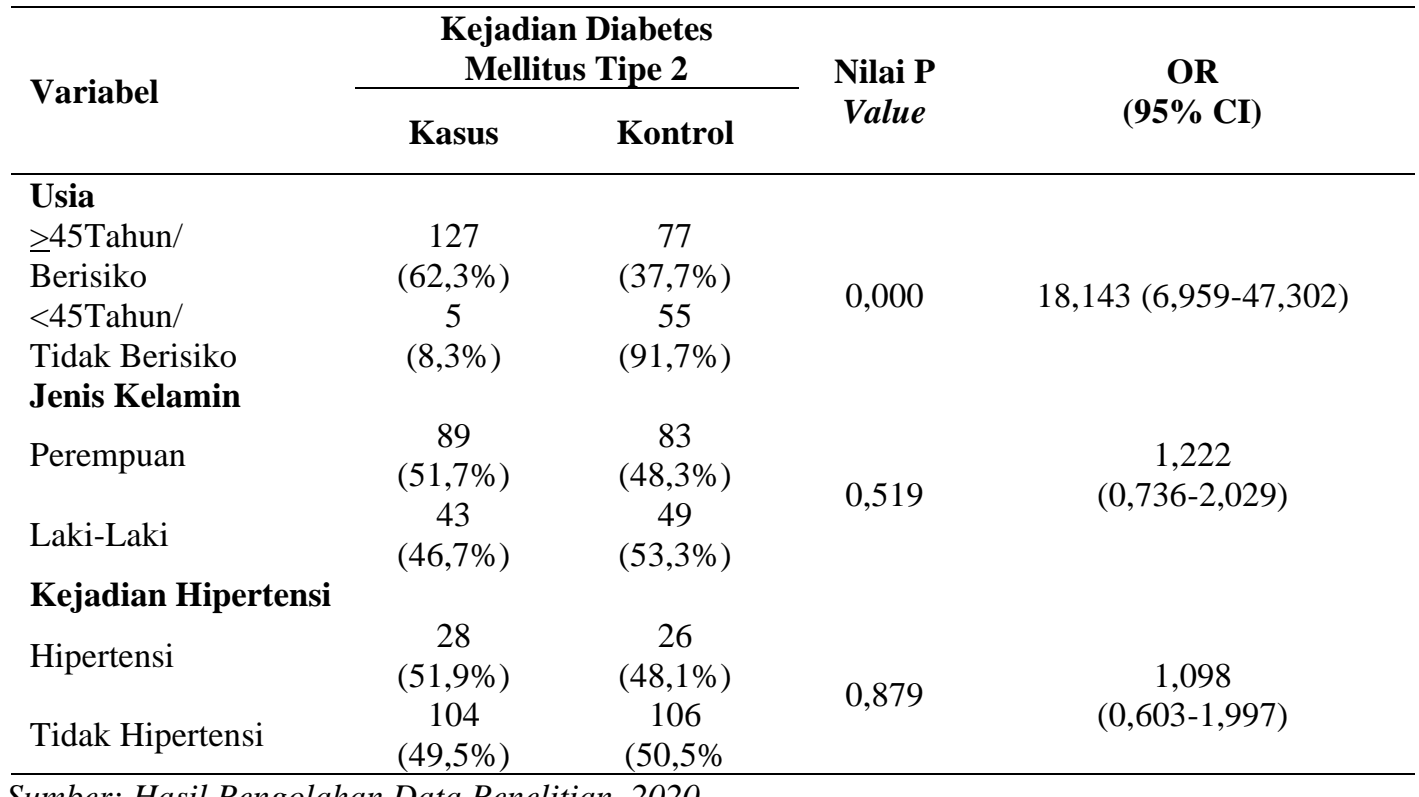

Sumber: Hasil Pengolahan Data Penelitian, 2020

Berdasarkan tabel 2 di atas menunjukkan bahwa dari 132 $(100,0 \%)$ pasien yang menderita diabetes mellitus tipe 2, ada 127 $(62,3 \%)$ pasien yang berusia $\geq 45$ tahun dan ada $5(8,3 \%)$ pasien yang berusia $<45$ tahun. Sedangkan dari 132 $(100,0 \%)$ pasien yang tidak menderita diabetes mellitus tipe 2 , ada $77(37,7 \%)$ pasien yang berusia $\geq 45$ tahun dan ada
$55(91,7 \%)$ pasien yang berusia $<45$ tahun.

Hasil uji statistik menggunakan chi-square diperoleh nilai $p$ value $=$ 0,000 dimana $p<\alpha(0,05)$, maka dapat disimpulkan bahwa ada hubungan antara usia dengan kejadian diabetes mellitus tipe 2 di Puskesmas Tugu Kecamatan Cimanggis Kota Depok tahun 2019. Berdasarkan hasil analisis diperoleh nilai OR $=18,143(95 \% \mathrm{CI}$ 
6,959-47,302), artinya kejadian diabetes mellitus tipe 2 pada pasien yang berusia $\geq 45$ tahun memiliki risiko 18,143 kali dibandingkan dengan pasien yang berusia $<45$ tahun.

Selanjutnya, tabel 2 di atas juga menunjukkan bahwa dari 132 $(100,0 \%)$ pasien yang menderita diabetes mellitus tipe 2 , ada $89(51,7 \%)$ pasien yang berjenis kelamin perempuan dan ada $43(46,7 \%)$ pasien yang berjenis kelamin laki-laki. Sedangkan dari $132(100,0 \%)$ pasien yang tidak menderita diabetes mellitus tipe 2, ada $83(48,3 \%)$ pasien yang berjenis kelamin perempuan dan ada 49 $(53,3 \%)$ pasien yang berjenis kelamin laki-laki. Hasil uji statistik menggunakan chi-square diperoleh nilai $p$ value $=0,519$ dimana $p>\alpha$ $(0,05)$, maka dapat disimpulkan bahwa tidak ada hubungan antara jenis kelamin dengan kejadian diabetes mellitus tipe 2 di Puskesmas Tugu Kecamatan Cimanggis Kota Depok tahun 2019. Berdasarkan hasil analisis diperoleh nilai $\mathrm{OR}=1,222(95 \% \mathrm{CI}$ 0,736-2,029), artinya kejadian diabetes mellitus tipe 2 pada pasien yang berjenis kelamin perempuan memiliki risiko 1,222 kali dibandingkan dengan pasien yang berjenis kelamin laki-laki.

Adapun pada variabel penderita hipertensi pada tabel 2 di atas menunjukkan bahwa dari 132 $(100,0 \%)$ pasien yang menderita diabetes mellitus tipe 2 , ada $28(51,9 \%)$ pasien yang mengalami hipertensi dan ada $104(49,5 \%)$ pasien yang tidak mengalami hipertensi. Sedangkan dari $132(100,0 \%)$ pasien yang tidak menderita diabetes mellitus tipe 2 , ada $26(48,1 \%)$ pasien yang mengalami hipertensi dan ada $106(50,5 \%)$ pasien yang tidak mengalami hipertensi. Hasil uji statistik menggunakan chi-square diperoleh nilai $p$ value $=0,879$ dimana $p>\alpha(0,05)$, maka dapat disimpulkan bahwa tidak ada hubungan antara hipertensi dengan kejadian diabetes mellitus tipe 2 di Puskesmas Tugu Kecamatan Cimanggis Kota Depok tahun 2019. Berdasarkan hasil analisis diperoleh nilai $\mathrm{OR}=1,098(95 \% \mathrm{CI}$ 0,603-1,997), artinya kejadian diabetes mellitus tipe 2 pada pasien yang mengalami hipertensi memiliki risiko 1,098 kali dibandingkan dengan pasien yang tidak mengalami hipertensi.

\section{DISKUSI}

1. Hubungan antara Usia dengan Kejadian Diabetes Mellitus Tipe 2 di Puskesmas Tugu Kecamatan Cimanggis Kota Depok Tahun 2019

Hasil penelitian ini sejalan dengan penelitian yang dilakukan oleh Kekenusa dkk (2018) yang menunjukkan bahwa terdapat hubungan antara umur dengan kejadian DM Tipe $2(\mathrm{p}=0,000)$ dengan nilai OR sebesar 7,6. Hal ini berarti bahwa orang dengan umur $\geq 45$ tahun memiliki risiko 8 kali lebih besar terkena penyakit DM Tipe 2 dibandingkan dengan orang yang berumur kurang dari 45 tahun.

Penelitian lain yang dilakukan oleh Radio Putro Wicaksono (2011) menyatakan bahwa terdapat hubungan antara usia dengan kejadian DM tipe 2 dengan nilai $p=0,000$. Didapatkan nilai OR sebesar 9,3 hal ini menunjukkan bahwa orang yang berusia $\geq 45$ tahun mempunyai risiko 9 kali untuk terjadinya DM tipe 2 dibandingkan dengan orang yang berusia $<45$ tahun dan secara statistik bermakna. Seseorang yang berusia $\geq 45$ tahun memiliki peningkatan risiko terhadap terjadinya DM dan intoleransi glukosa oleh karena faktor degeneratif yaitu menurunnya fungsi tubuh untuk memetabolisme glukosa. Namun kondisi ini ternyata tidak hanya disebabkan oleh faktor usia saja, tetapi juga pada lamanya penderita bertahan pada kondisi tersebut.

American Diabetes Association (ADA) (2011) menyatakan bahwa risiko diabetes mellitus tipe 2 meningkat seiring dengan bertambahnya usia. Mekanisme yang mendasari lebih tingginya risiko diabetes mellitus tipe 2 pada individu yang berusia lebih tua adalah adanya peningkatan komposisi lemak dalam tubuh yang terakumulasi di abdomen, sehingga memicu terjadinya obesitas sentral. Obesitas sentral selanjutnya memicu terjadinya resistensi insulin yang merupakan proses awal diabetes mellitus tipe 2 (Suastika et al, 2012).

WHO juga menyebutkan bahwa setelah seseorang mencapai umur 40 tahun 
maka kadara glukosa darah naik 1-2 mg\% pertahun pada saat puasa dan akan naik sekitar 5,6 - $13 \mathrm{mg} \%$ pada 2 jam setelah makan. Berdasarkan hal tersebut tidaklah mengherankan apabila faktor usia merupakan faktor utama terjadinya kenaikan prevalensi diabetes mellitus khususnya tipe II serta gangguan toleransi glukosa (Isselbacher et al, 2000 dalam Fanani, 2020).

2. Hubungan antara Jenis Kelamin dengan Kejadian Diabetes Mellitus Tipe 2 di Puskesmas Tugu Kecamatan Cimanggis Kota Depok Tahun 2019

Hasil penelitian ini sejalan dengan penelitian yang dilakukan oleh Rahayu, dkk (2011) yang menyatakan bahwa tidak ada hubungan yang bermakna antara jenis kelamin dengan kejadian diabetes mellitus dengan nilai $p=0,157$. Hasil penelitian lain yang dilakukan oleh Isnaini dan Ratnasari (2018) juga menyatakan bahwa faktor jenis kelamin tidak berpengaruh secara signifikan terhadap kejadian DM dengan nilai $\mathrm{p}=0,63$.

Hasil yang sama juga didapatkan pada penelitian yang dilakukan oleh Fatmawati (2010) yang menunjukkan hasil analisis uji chi square dengan nilai $p$ value $=0,733(>\alpha=0,05)$, artinya tidak ada hubungan yang signifikan antara jenis kelamin dengan kejadian DM tipe 2 . Meskipun para pasien di rumah sakit tersebut didominasi oleh pasien perempuan, namun jenis kelamin ini secara nyata tidak berhubungan dengan terjadinya DM tipe 2. Hasil penelitian ini sesuai dengan penelitian yang dilakukan di Amerika yaitu penderita DM pada perempuan lebih banyak dibandingkan laki-laki, namun di Augsburg 5,8 per 1.000/orang/tahun pada laki-laki dan 4,0 per 1.000 /orang/tahun pada perempuan. Hasil penelitian ini membuktikan bahwa laki-laki maupun perempuan memiliki risiko yang sama untuk terkena DM. Hasil penelitian ini didukung oleh penelitian di Indonesia yang dilakukan oleh Riskesdas pada tahun 2007, yakni prevalensi diabetes mellitus tidak berbeda menurut jenis kelamin. Hasil penelitian Riskesdas didapatkan bahwa prevalensi diabetes mellitus untuk jenis kelamin perempuan dan laki-laki hasilnya sama yaitu sebesar 1,1\% (Riskesdas, 2008).
Menurut Boku (2019) menyatakan bahwa jenis kelamin tidak berpengaruh terhadap kenaikan atau penurunan kadar gula darah pada penderita diabetes mellitus tipe 2 karena baik pria maupun wanita memiliki risiko yang sama besar mengalami penyakit diabetes mellitus dan kadar gula darah menurut jenis kelamin sangat bervariasi serta yang membedakan yaitu karena faktor-faktor lain yang mempengaruhi kadar gula darah.

3. Hubungan antara Hipertensi dengan Kejadian Diabetes Mellitus Tipe 2 di Puskesmas Tugu Kecamatan Cimanggis Kota Depok Tahun 2019

Hasil penelitian ini sejalan dengan penelitian yang dilakukan oleh Fitriyani (2012) yang menunjukkan bahwa tidak ada hubungan yang signifikan antara tekanan darah dengan kejadian DM Tipe 2 dengan nilai $\mathrm{p}=0,862(\mathrm{p}>0,05)$. Selain itu, nilai OR menunjukkan bahwa orang yang hipertensi memiliki risiko 1,2 kali untuk menderita DM Tipe 2 dibandingkan dengan orang yang tidak hipertensi. Hasil uji tersebut tidak signifikan dikarenakan dari 500 responden, sebagian besar responden tidak mengalami hipertensi. Hal ini terlihat dari persentase responden yang tidak mengalami hipertensi sebanyak 338 $(67,6 \%)$ sedangkan responden yang mengalami hipertensi sebanyak 162 $(32,4 \%)$. Hasil penelitian lain yang dilakukan oleh Isnaini dan Ratnasari (2018) diperoleh nilai $\mathrm{p}$ value $=0,689$, artinya tidak ada hubungan antara tekanan darah dengan kejadian DM tipe 2 di wilayah kerja Puskesmas I Wangon karena kemungkinan responden yang menderita hipertensi sudah mendapatkan pengobatan.

Hasil penelitian ini berbeda dengan penelitian yang dilakukan oleh Sri Widayati Alfiyah (2011) yang menunjukkan nilai $p$ value $=0,001(<\alpha=$ $0,05)$ artinya ada hubungan antara hipertensi dengan kejadian diabetes mellitus pada pasien rawat jalan di Rumah Sakit Umum Daerah Kota Semarang tahun 2010. Diperoleh nilai ood ratio $(\mathrm{OR})=$ 4,330 (95\% CI = 1,800-10,416), sehingga dapat disimpulkan bahwa responden yang menderita penyakit hipertensi mempunyai risiko terkena penyakit diabetes mellitus 4,330 kali lebih besar dibandingkan 
responden yang tidak menderita penyakit hipertensi.

Apabila kondisi hipertensi pada seseorang dibiarkan tanpa perawatan, maka dapat menyebabkan penebalan pembuluh darah arteri yang membuat diameter pembuluh darah menjadi sempit. Hal ini akan menyebabkan proses pengangkutan glukosa dari dalam darah menjadi terganggu (Zieve, 2012 dalam Affisa, 2018).

\section{KESIMPULAN}

Berdasarkan hasil penelitian dan pembahasan terkait hubungan usia, jenis kelamin dan hipertensi dengan kejadian diabetes mellitus tipe 2 di Puskesmas Tugu Kecamatan Cimanggis Kota Depok Tahun 2019, maka dapat disimpulkan gambaran karakteristik pasien menunjukkan bahwa sebagian besar pasien beralamat di RW 08 sebanyak $35(13,2 \%)$ pasien, jenis kunjungan pasien sebagian besar adalah pasien lama sebanyak $238(90,2 \%)$ pasien, sebagian besar pasien menggunakan jenis bayar BPJS sebanyak $203(76,9 \%)$ pasien dan sebagian besar pasien berada di poli umum sebanyak 152 $(57,6 \%)$ pasien. Gambaran faktor determinan kejadian diabetes mellitus tipe 2 menunjukkan bahwa sebagian besar pasien berusia $\geq 45$ tahun sebanyak 204 (77,3\%) pasien, sebagian besar pasien berjenis kelamin perempuan sebanyak $172(65,2 \%)$ pasien dan sebagian besar pasien tidak mengalami hipertensi sebanyak 210 $(79,5 \%)$ pasien. Penelitian ini menghasilkan temuan bahwa ada hubungan antara usia dengan kejadian diabetes mellitus tipe 2 di Puskesmas Tugu Kecamatan Cimanggis Kota Depok Tahun 2019, tidak ada hubungan antara jenis kelamin dengan kejadian diabetes mellitus tipe 2 di Puskesmas Tugu Kecamatan Cimanggis Kota Depok Tahun 2019 dan tidak ada hubungan antara hipertensi dengan kejadian diabetes mellitus tipe 2 di Puskesmas Tugu Kecamatan Cimanggis Kota Depok Tahun 2019. Hasil determinan yang berhubungan dengan kejadian diabetes mellitus adalah usia yang merupakan karakteristik yang tidak dapat dikelola. Program pencegahan dan promosi kesehatan berupa skrining pada kelompok umur di atas 45 tahun diperlukan dalam mendeteksi dan menangani diabetes dengan baik oleh puskesmas.

\section{DAFTAR PUSTAKA}

Affisa, S.N. 2018. Faktor-faktor Risiko Diabetes Melitus Tipe 2 Pada Laki-laki di Kelurahan Demangan Kota Madiun. Skripsi. Program Studi S1 Kesehatan Masyarakat. STIKES Bhakti Husada Mulia, Madiun.

Alfiyah, S.W. 2011. Faktor Risiko yang Berhubungan dengan Kejadian Penyakit Diabetes Melitus Pada Pasien Rawat Jalan di Rumah Sakit Umum Pusat Dr. Kariadi Semarang Tahun 2010. Skripsi. Jurusan Ilmu Kesehatan Masyarakat. Universitas Negeri Semarang.

Badan Penelitian dan Pengembangan Kesehatan DepKes RI. 2008. Laporan Hasil Riset Kesehatan Dasar (RISKESDAS) Nasional 2007. Jakarta.

Boku, A. 2019. Faktor-faktor yang Berhubungan Terhadap Kadar Gula Darah Pada Penderita Diabetes Melitus Tipe II di RS PKU Muhammadiyah Yogyakarta. Naskah Publikasi. Yogyakarta: Fakultas Ilmu Kesehatan. Universitas 'Aisyiyah.

Fanani, A. 2020. Hubungan Faktor Risiko dengan Kejadian Diabetes Mellitus. Jurnal Keperawatan, Vol. 12 (3), hal. 371-378.

Fatmawati, A. 2010. Faktor Risiko Kejadian Diabetes Melitus Tipe 2 Pasien Rawat Jalan (Studi Kasus di Rumah Sakit Umum Daerah Sunan Kalijaga Demak). Skripsi. Jurusan Ilmu Kesehatan Masyarakat. Universitas Negeri Semarang.

Fitriyani. 2012. Faktor Risiko Diabetes Melitus Tipe 2 di Puskesmas Kecamatan Citangkil dan Puskesmas Kecamatan Pulo Merak Kota Cilegon. Skripsi. Fakultas Kesehatan Masyarakat. Universitas Indonesia, Depok.

Imelda, S. 2019. Faktor-faktor yang Mempengaruhi Terjadinya Diabetes Melitus di Puskesmas Harapan Raya Tahun 2018. Scientia Journal, Vol. 8 (1): 2019.

Isnaini, N., Ratnasari. 2018. Faktor Risiko Mempengaruhi Kejadian Diabetes Mellitus Tipe Dua. Jurnal Keperawatan dan Kebidanan Aisyiyah, Vol. 14 (1), hal. 59-68.

Kekenusa, J.S., Ratag, B.T., Wuwungan, G. 2013. Analisis Hubungan antara Umur dan Riwayat Keluarga Menderita DM 
dengan Kejadian Penyakit DM Tipe 2 pada Pasien Rawat Jalan di Poliklinik Penyakit Dalam BLU RSUP Prof. Dr. R.D. Kandou Manado.

Kemenkes RI. 2019. INFODATIN. Pusat Data dan Informasi Kementerian Kesehatan RI: Hari Diabetes Sedunia Tahun 2018. Jakarta Selatan: Kemenkes RI.

Masruroh, E. 2018. Hubungan Umur dan Status Gizi dengan Kadar Gula Darah Penderita Diabetes Melitus Tipe II. Jurnal Ilmu Kesehatan, Vol. 6 (2).

Mildawati., Diani, N., Wahid, A. 2019. Hubungan Usia, Jenis Kelamin dan Lama Menderita Diabetes dengan Kejadian Neuropati Perifer Diabetik. Caring Nursing Journal, Vol. 3 (2), ISSN: 2580-0078.

Nurayati, L., Adriani, M. 2017. Hubungan Aktifitas Fisik dengan Kadar Gula Darah Puasa Penderita Diabetes Melitus Tipe 2. Amerta Nutr, hal. 80-87.

PERKENI. 2015. Konsensus Pengelolaan dan Pencegahan Diabetes Mellitus Tipe 2 di Indonesia 2015. Jakarta: Pengurus Besar
Perkumpulan Endokrinologi Indonesia (PB PERKENI).

Rahayu, P., Utomo, M., Setiawan, M.R. 2011. Hubungan antara Faktor Karakteristik, Hipertensi dan Obesitas dengan Kejadian Diabetes Mellitus di Rumah Sakit Umum Daerah Dr. H. Soewondo Kendal.

Suastika, K., Dwipayana, P., Semadi, M.S., Kuswardhani, R.A.T. 2012. Age is an Important Risk Factor for Type 2 Diabetes Mellitus and Cardiovascular Diseases. InTech.

Wicaksono, R.P. 2011. Faktor-faktor yang Berhubungan dengan Kejadian Diabetes Melitus Tipe 2 (Studi Kasus di Poliklinik Penyakit Dalam Rumah Sakit Dr. Kariadi). Artikel Hasil Penelitian Karya Tulis Ilmiah. Fakultas Kedokteran. Universitas Diponegoro, Semarang.

Widyasari, N. 2017. Hubungan Karakteristik Responden dengan Risiko Diabetes Melitus dan Dislipidemia Kelurahan Tanah Kalikedinding. Jurnal Berkala Epidemiologi, Vol. 5 (1), hal. 130-141. 